〔56〕ポリ酷酸ビニル部分ケン化物水溶液の濁度に 及ぼすケン化条件の影響**

(1959 年 12 月 23 日受理)

内藤龍之住

\begin{abstract}
要 旨 ポリ䁏酸ビニル(以下 PVAc と略)部分ケン化物水容液の透明度が低、原因について梌討寸る

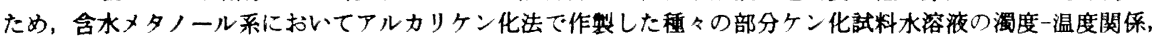
あるい注 $\mathrm{NaCl}$ 水による沈殿曲線を求め，これより分子間の酷酸基組成の不均一性拉上び分子内の酢酸基配

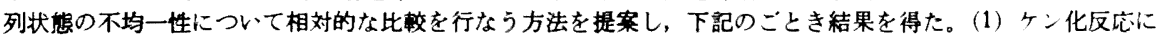

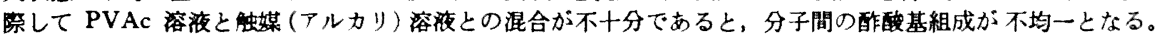
これは工業的な堨合，特に留意すべき点である。(2) PVAc 溶液篧度は，30\% 以下では生成する部分ケン化

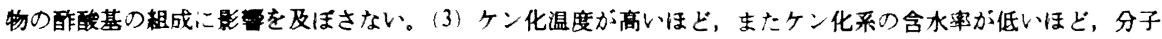
間の酷酸基組成および 分子内の酸酸基配列状热ともに不均一となり，水楁液の透明度が低下する原因となる。 （4）上の事実はケン化沮度が高、将と，また含水事が低、汪と，ケン化反応の加速現象が亚盛に起っているこ とを示すものと考えられる。
\end{abstract}

\section{1. 楮言}

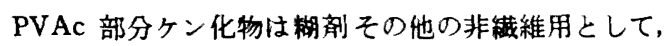
最近ますます広く使用せられつつあるが，これらは水溶 液として用いられることが多く，したがってその透明度 および沈殿性が重要な性質として考えられる。元来 PV A は水溶性高分子であるか，水酸基の水素結合により結 晶性が強く, 溶解性が抑制されており,むしろ数\%程度 の酶酸基が存在する方が結晶性が低下し, 溶解性も良好 であることが知られている。しかし酢酸基がさらに増加 すると, 酢酸基自身の㻋水性のため溶解性を堿し，水溶 液の透明度も低下する。特に PVAc 部分ヶン化物水溶 液仙他の多くの高分子溶夜と異なり低温易溶性 ${ }^{1}$ であ りしたがって高温における透明度が低下するといら特 異性を有している。

PVAcのケン化反応には普通加速現象が伴い,この結 果として分子間の酢酸基組成の不均一性, 分子内の酢酸 基配列の不均一性（酢酸基が無秩序に分布しているのを 均一な分布, 集団的に存在しているのを不均一な分布と する)を生し，これらは溶解性，したがって水溶液の透明 度に対して影響を及ぼすことが考えられる。たとえば高 山氏 ${ }^{2)}$ は部分ヶン化物水溶液に対し, 正プロピルアルコー ルを沈殿剤として用いて分別し, 各区分の酢酸基を定量 することにより，酶酸基に関して相当の不均一性があり， かつ水溶液の透明度が低、試料ほどこの不均一性が大き いことを定性的に認めた。このような不均一性はヶン化 条件に支配されるものと思われ，できるだけ組成の均一 な部分ケン化物をつくることが透明度を高める上におい て必要な条件であると思われる。ケン化条件と酢酸基組

* 倉敖レイヨン株式会社富山工場(富山市莲町)

** 本報告を「ポリビニルアルコールの溶解状態に関する研 究、第 10 報とする。
成との関倸については, 桜田氏ら ${ }^{8)}$ の報告があるが, こ れはケン化方法, すなわち可逆反応系と含水メタノール 系などの比較であり，ここでは工業的に最も重要である 含水メタノール系のケン化反応における, より細かいケ ン化条件（たとえばケン化温度，ケン化采の含水率など） の影響について詳細に測定した。

\section{2. 実験方法および試料}

酶酸基の分布を測定する場合, 試料を分別して酶酸基 を定量する方法は，絶対值が得られるといら点に扔いて すぐれているが, 測定に際し多くの試料, 時間, 労力を 必要とする。これらを考虑して下記の 2 法を採用した。

\section{1 透明度の温度依存性を測定する方法}

前述のごとく PVAc 部分ケン化物水溶液は高温ほど 濁度が增加する。この濁りの生ずる温度は酢酸基量およ びその分布状態によって異なるから，一定濃度の水溶液 について温度による濁度の変化を追跡し, その曲線の傾 斜より分子間の酢酸基の不均一性を, また曲線の位置 (た とえば平均沈殿温度)上り分子内の不均一性についての 相対的知見を得ることができる。もちろんこの両者は完 全に独立した性質ではなく影響を及ぼし合うが，一応相 対的な比較を目的とする場合はこれで十分であろう。装 㯰には加熱型光電管式濁度計を用い, $0.2 \mathrm{~g} / l$ の水溶液を ガラスセルに入れ，かきまぜつつ， $1^{\circ} \mathrm{C} / 10 \mathrm{~min}$ の割合 で温度を上年せしめて連続的に濁度を測定した。

\section{$2.2 \mathrm{NaCl}$ 水による沈殿性を利用する方法}

一定濃度 $(1 \mathrm{~g} / l)$ の試料水溶液と一定澱度 $(50 \mathrm{~g} / l$ または $80 \mathrm{~g} / l)$ の $\mathrm{NaCl}$ 水溶液とをそれぞれ異なった割合に混合 し(混合は $30^{\circ} \mathrm{C}$ において試料溶液をかきまぜつつ $\mathrm{NaCl}$ 水溶淮を滴下する), $30^{\circ} \mathrm{C}$ に 2 時間放置後溶液の濁度を測 定し, 沈殿戍濃度と濁度との関倸をプロットして,この 
曲線より (1) と同様酢酸基組成および配列状態の相対的 知見を得た。

試料は $60^{\circ} \mathrm{C}$, タノール $20 \%$ 溶液重合で得た PVAc をアセトンー水系で粗分別し，平均重合度 1960 の粗分別 物を原料とし，含水メタノール采でケン化して部分ヶン 化物をつくった。詳細なケン化条件は実験結果とともに 記す。なおケン化に使用したアルカリはすべて水溶液で ある。

\section{3. 実験結果および考察}

\section{1 種々のケン化度の部分ケン化物の混合物水溶 液 の濁度}

前述のごとく, 酢酸基の組成が不均一な試料ほど水溶 液の透明度が低下することが知られているが，これは試 料の中に溶解性が悪い低ヶン化度のものが混入している ためか，またはそうでなくても種々の程度にヶン化され た分子の混合物であるため，各分子によって溶解状態が 異なり，ちょうど脱混合のような現象を起して溶液が濁
るのか, そのいずれかを調べるため種々の程度にケン化 してつくった部分ケン化物の混合水溶液の透明度を測定 した。詳細な結果は省略するが，単独で透明度が良好な 試料を数種類混合しても濁らず，透明度が低、試料を 1 種類でも混合すると，その混合量に応じて透明度が低下 することがわかり，透明度低下の原因は低ヶン化度分子 (重合度 1700 程度でケン化度約 82 モル\%以下) が存在す るためであることがわかる。したがって前記の実験方法 により不均一性が測定できる。

\section{2 混合物水容夜についての予備試験}

第 1 表に示すように, ケン化条件が同一でアルカリモ ル比のみを相違してつくった種々のケン化度の試料を混 合して, 平均のケン化度を求め, それと等しいケン化度 を持つ単独物との沈殿性の比較を行なった。温度-濁度 関係を第 1 図(イ)に, $\mathrm{NaCl}$ 量-濁度関係を第 1 図(口)に 示す。

第 1 図より明らかなよ5に, 分子間の酢酸基の組成が 不均一であると考えられる混合物の方がいずれも曲線の

第 1 表 単独物と混合物とのケン化度

\begin{tabular}{|c|c|c|c|c|c|c|}
\hline 種 類 & $\begin{array}{c}\text { 単独物のケン化度 } \\
(\text { モル\%) }\end{array}$ & $\begin{array}{l}\text { 混 合 比 } \\
\text { (wt \%) }\end{array}$ & $\begin{array}{c}\text { 混合物のケン化度 } \\
(モ ル \%)\end{array}$ & $\begin{array}{c}\text { 単独物のケン化度 } \\
(\text { モル\%) }\end{array}$ & $\begin{array}{c}\text { 混 合 比 } \\
(\text { wt \%) }\end{array}$ & 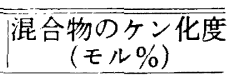 \\
\hline 単独物 & 78.6 & - & - & 77.4 & - & - \\
\hline 混 合物 & $\begin{array}{l}80.9 \\
78.6 \\
75.4\end{array}$ & $\begin{array}{l}33.33 \\
33: 33 \\
33.33\end{array}$ & 78.4 & $\begin{array}{l}80.9 \\
77.4 \\
76.4 \\
74.3\end{array}$ & $\begin{array}{l}25 \\
25 \\
25 \\
25\end{array}$ & 77.4 \\
\hline
\end{tabular}

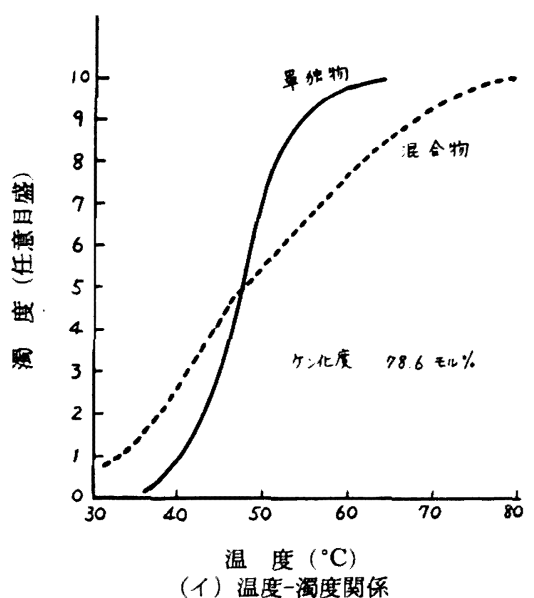

（イ）温度-濁度関俰

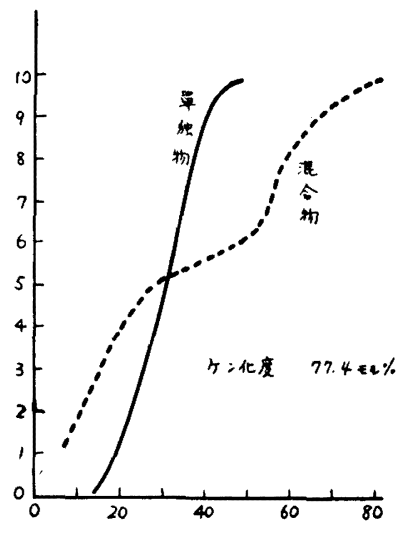

系中の $\mathrm{NaCl}$ 浱度 $(\mathrm{g} / \mathrm{l})$ (口) $\mathrm{NaCl}$ 浱度一濁度関倸 $\left(30^{\circ} \mathrm{C}\right)$

第 1 図 混合物と単独物との溜度の比較

傾斜*は小さい。またこれらの試 料は同一ヶン化条件でつくられた ゆえ, 分子内の酢酸基の配列状態 には差がないものと推定される が，曲線の位置をその平均沈殿温 度*および平均沈殿組成*で比較す れば両者で全く差がみられない。 以上の実験結果より,この実験方 法は本実験目的のために十分利用 しらるものと思われる。

\section{3 ケン化時におけるかきま ぜの影蛘}

部分ケン化物作製の場合は，厂 ルカリのモル比が小さいためケン 化系の混合状態が十分でないと， アルカリ濃度が場所によって一定

でなく,そのために酢酸基組成の不均一性を生ずる原因
となる。この現象は, 工業的に濃厚溶液で短時間にヶン
化を終了させるよ5な場合特に重要であり, また本実験
の目的であるヶン化系の含水率, PVAc 溶液濃度, ケン

でなく, そのために酢酸基組成の不均一性を生ずる原因
となる。この現象は, 工業的に濃厚溶液で短時間にケン
化を終了させるよ5な場合特に重要であり, また本実験
の目的であるケン化系の含水率, PVAc 溶液濃度, ケン

でなく, そのために酢酸基組成の不均一性を生ずる原因
となる。この現解は, 工業的に濃厚溶液で短時間にケン
化を終了させるような場合特に重要であり, また本実験
の目的であるケン化系の含水率, PVAc 溶液濃度, ケン

でなく, そのために酢酸基組成の不均一性を生ずる原因
となる。この現稣は, 工業的に濃厚溶液で短時間にケン
化を終了させるような場合特に重要であり, また本実験
の目的であるケン化系の含水率, PVAc 溶液濃度, ケン

\footnotetext{
* 平均沈殹洞度としては温度一溷度曲線において。，それ以上沮

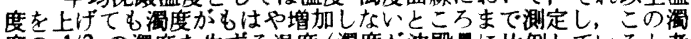

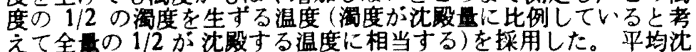
貶組成も同様である。曲線の傾科はこれら平均位隤の傾斜で比較 した。以下の実鸦結果につけても同梯である。
} 
化温度などの本質的な影響と区別して考えねばならな い。もちろんこの混合状態の影響はかきまぜ器の回転 数, PVAc 濃度, 使用アルカリ濃度, PVAc 溶液とアル カリ溶夜との混合比, ケン化速度など種々の因子に支配 されるわけであり，非常に複雑であるが，ここでは一例 としてかきませ器の回転数および使用アルカリの濃度の 影響について簡単に示す。第 2 図より明らかなように曲

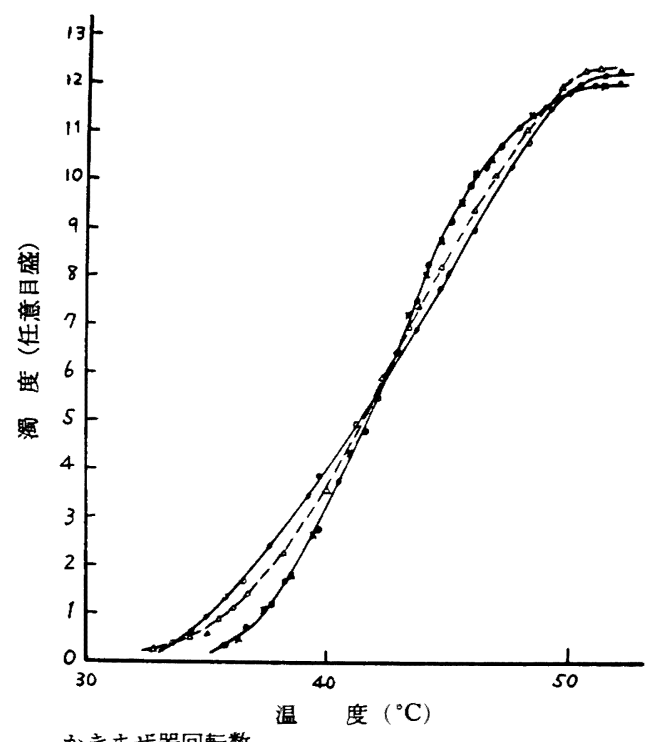

かきまぜ器回転数

: $1000, x: 500, \bigcirc: 200, \Delta: 500 \mathrm{rpm} \quad(260 \mathrm{~g} / \mathrm{l}$ アルカリ使用)

共通条件：PVAc 作度 $15 \%$ ，ケン化温度 $30^{\circ} \mathrm{C}$ ，ケン化 系含水率 $5.2 \%$, 使用アルカリ度 $30 \mathrm{~g} / l$, アルカリ モル比 0.0116 , ケン化度 74.5 モル\%

第 2 図 かきませ条件を相違してつくった 試料の濁度一温度関倸
線の傾斜は, かきまぜ器が $1000 \mathrm{rpm}$ と $500 \mathrm{rpm}$ の場合 とでほとんど差がないが, $200 \mathrm{rpm}$ では小さくなり，ま た $500 \mathrm{rpm}$ の場合でも使用アルカリ濃度が高い場合は (同一モル比であるから使用アルカリ量が少ない) 傾斜が 小で，これらの場合は混合が不十分なため分子間の酶酸 基組成が不均一になったことを示している。なお平均沈 殿温度は四つの試料とも同一 $\left(\right.$ 約 $\left.42^{\circ} \mathrm{C}\right)$ であり, 試料の 平均ヶン化度が等しい $(74.5$ モル％)ことと考え合わせれ ば，分子内の酶酸基の配列状態には特に差がないことが わかる。以下の実験においては, これらの混合の影響が 現われない条件を選んで試料を作製した。

\section{4 ケン化温度の影祭}

第 2 表のごとく, 温度を異にしてケン化した部分ヶン 化物試料水溶液について, 温度一濁度曲楾および $\mathrm{NaCl}$ 濃度一濁度曲線を求めた。なおケン化に際しては混合状 態を均一にするため, アルカリ添加後 $0^{\circ} \mathrm{C} て ゙ 1$ 時間十分 かきまぜ後，それぞれ所定の温度でケン化せしめた。

測定結果を第 3 および 4 図に示す。第 3 図は多くの試 料について温度一濁度曲線を求め, 曲線の傾斜および平 均沈殿温度とヶン化度とをプロットしたものであり，第 4 図は同一ケン化度の試料を選び, $\mathrm{NaCl}$ 水による沈殿 曲線を示す。これらの図より明らかなように同一ケン化 度の試料を比較すれば, ケン化温度が低いほど曲線の傾 斜は大きく，かつ平均沈殿温度および組成が高いことが わかり，ケン化温度が低、試料ほど分子間および分子内 の酢酸基組成が均一であると推定される（分子内の酢酸 基組成が均一すなわち無秩序なほど溶解性がすぐれてい ることはすでに明らかにされている゙。

第 2 表 試料のケン化条件

PVAc 濃度 $5 \%$, 使用アルカリ濃度 $40 \mathrm{~g} / \mathrm{l}$, ケン化系の含水涐 $6.0 \%$

\begin{tabular}{|c|c|c|c|c|c|c|c|}
\hline 番 号 & $\begin{array}{c}\text { ケン化 } \\
\text { 温度 }\left({ }^{\circ} \mathrm{C}\right) \\
\end{array}$ & $\begin{array}{c}\text { アルカリ } \\
\text { モル比 }\end{array}$ & $\begin{array}{l}\text { ケン化度 } \\
\text { (モル\%) }\end{array}$ & 番 号 & $\begin{array}{c}\text { ケン化 } \\
\text { 温度 }\left({ }^{\circ} \mathrm{C}\right)\end{array}$ & $\begin{array}{c}\text { アルカリ } \\
\text { モル比 }\end{array}$ & $\begin{array}{l}\text { ケン化度 } \\
(モ ル \%)\end{array}$ \\
\hline 68 & \multirow{4}{*}{0} & 0.0083 & 77.2 & 18 & \multirow{5}{*}{45} & 0.0215 & 81.5 \\
\hline 67 & & 0.0077 & 74.6 & 43 & & 0.0191 & 80.8 \\
\hline 66 & & 0.0073 & 73.3 & 44 & & 0.0173 & 77.0 \\
\hline & & & & 45 & & 0.0154 & 75.7 \\
\hline 11 & 20 & 0.0086 & 74.6 & 54 & & 0.0155 & 74.8 \\
\hline 32 & \multirow{4}{*}{30} & 0.0187 & 78.6 & 73 & \multirow{4}{*}{60} & 0.0211 & 81.3 \\
\hline 33 & & 0.0168 & 77.4 & 76 & & 0.0194 & 77.4 \\
\hline 23 & & 0.0137 & 76.4 & 74 & & 0.0186 & 75.2 \\
\hline 28 & & 0.0116 & 74.8 & 77 & & 0.0184 & 74.6 \\
\hline
\end{tabular}



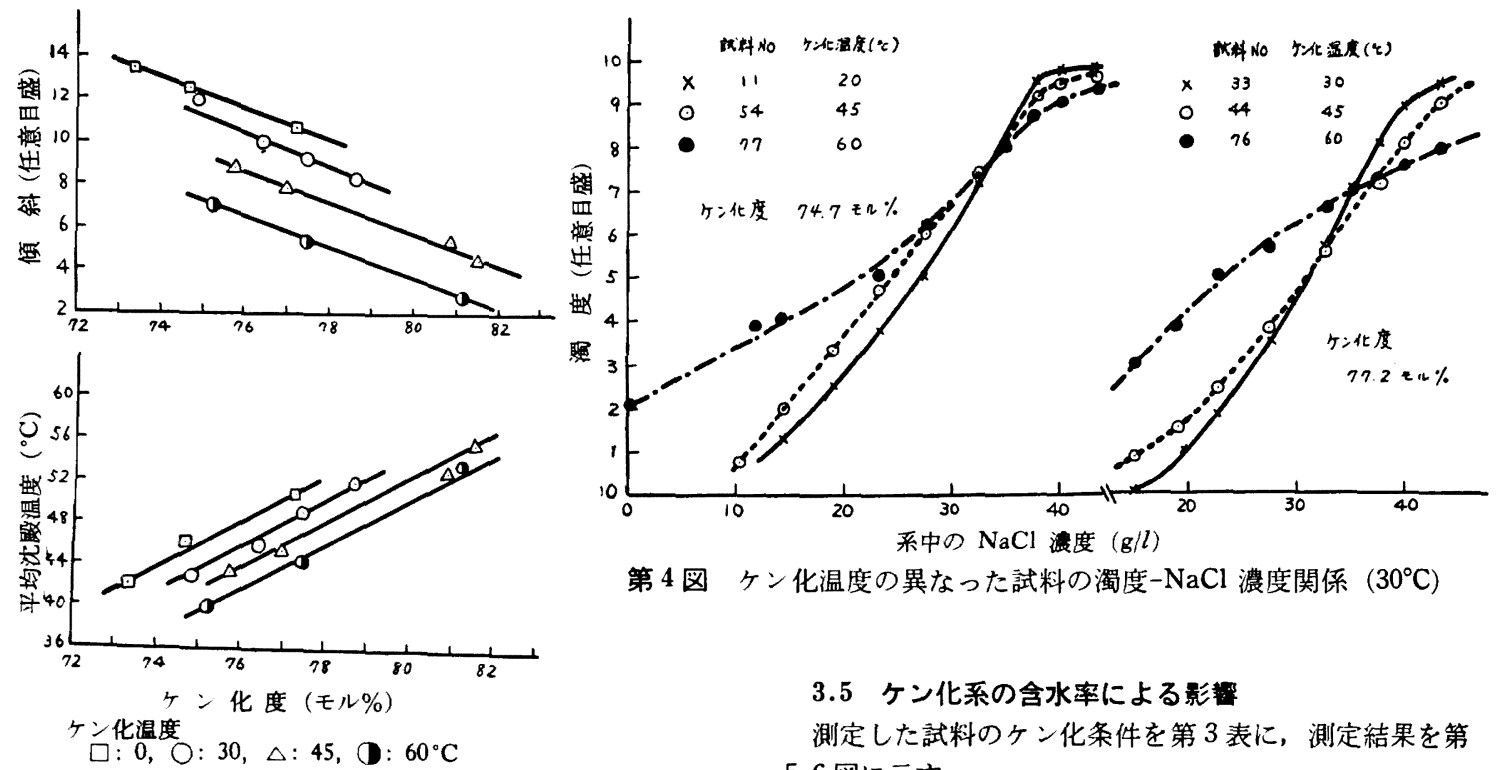

第 4 図 ケン化温度の異なった試料の瀷度 $-\mathrm{NaCl}$ 濃度関係 $\left(30^{\circ} \mathrm{C}\right)$

第 3 図ヶン化温度の巽なった試料について の濁度一温度関倸の傾斜および平均沈殿温度

第 3 表 試料のケン化条件

PVAc 濃度 $5 \%$, 使用アルカリ濃度 $40 \mathrm{~g} / l$, ケン化温度 $30^{\circ} \mathrm{C}$

\begin{tabular}{|c|c|c|c|c|c|c|c|}
\hline 番 号 & $\begin{array}{l}\text { ケン化亲の } \\
\text { 含水率 }(\%)\end{array}$ & $\begin{array}{c}\text { アルカリ } \\
\text { モル比 }\end{array}$ & $\begin{array}{l}\text { ケン化度 } \\
(モ ル \%)\end{array}$ & 番 号 & $\begin{array}{l}\text { ケン化采の } \\
\text { 含水率 }(\%)\end{array}$ & $\begin{array}{c}\text { アルカリ } \\
\text { モル比 }\end{array}$ & $\begin{array}{l}\text { ケン化度 } \\
\text { (モル\%) }\end{array}$ \\
\hline $\begin{array}{l}91 \\
92 \\
93\end{array}$ & 1.5 & $\begin{array}{l}0.0037 \\
0.0032 \\
0.0028\end{array}$ & $\begin{array}{l}80.9 \\
78.6 \\
75.4\end{array}$ & $\begin{array}{l}22 \\
32\end{array}$ & & $\begin{array}{l}0.0200 \\
0.0187\end{array}$ & $\begin{array}{l}81.1 \\
78.6\end{array}$ \\
\hline $\begin{array}{l}86 \\
87 \\
88\end{array}$ & 10.5 & $\begin{array}{l}0.0203 \\
0.0219 \\
0.0235\end{array}$ & $\begin{array}{l}76.4 \\
79.0 \\
81.1\end{array}$ & $\begin{array}{l}33 \\
23 \\
28\end{array}$ & 6.0 & $\begin{array}{l}0.0168 \\
8.0137 \\
0.0116\end{array}$ & $\begin{array}{l}77.4 \\
76.4 \\
74.8\end{array}$ \\
\hline
\end{tabular}

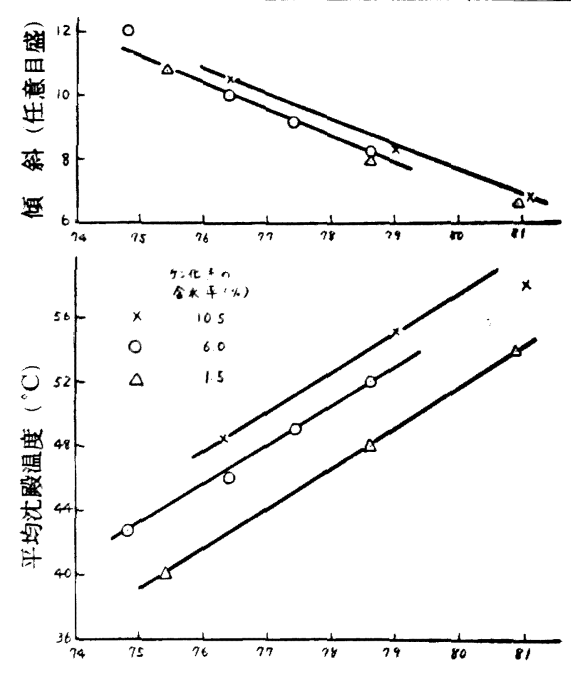

ケン化度 (モル\%)

第 5 図ヶン化采の含水率の異なった試料について の濁度一温度関係の傾斜および平均沈殿温度

\section{5 ケン化系の含水率による影瞥}

測定した試料のケン化条件を第 3 表に, 測定結果を第 5,6 図に示す。 
第 4 表 試料のケン化条件

ケン化温度 $30^{\circ} \mathrm{C}$ 、ケン化系の含水率 $4.0 \%$, 使用アルカリ湿度 $40 \mathrm{~g} / \mathrm{l}$

\begin{tabular}{|c|c|c|c|c|c|c|c|}
\hline 番 品 & $\begin{array}{c}\text { PVAc 瀩度 } \\
(\text { wt \%) }\end{array}$ & $\begin{array}{c}\text { アルカリ } \\
\text { モル比 }\end{array}$ & $\begin{array}{l}\text { ケン化度 } \\
(亡 ル \%)\end{array}$ & 番 号 & $\begin{array}{c}\text { PVAc 檟度 } \\
(\text { wt \% })\end{array}$ & $\begin{array}{l}\text { アルカリ } \\
\text { モル比 }\end{array}$ & $\begin{array}{l}\text { ケン化度 } \\
(モ ル \%)\end{array}$ \\
\hline $\begin{array}{l}103 \\
104 \\
\end{array}$ & 16.7 & $\begin{array}{l}0.012 \\
0.010 \\
\end{array}$ & $\begin{array}{l}78.9 \\
74.8 \\
\end{array}$ & \multirow{2}{*}{$\begin{array}{l}111 \\
112\end{array}$} & \multirow{2}{*}{29.2} & 0.012 & \multirow{2}{*}{$\begin{array}{l}80.0 \\
75.4\end{array}$} \\
\hline 108 & 23.0 & 0.011 & 78.0 & & & 0.010 & \\
\hline
\end{tabular}

図より明らかなように同一ケン化度の試料では，いず れもケン化系の含水事が高い詿料ほど曲線の傾斜が大き く，かつ平均沈殿湿度および組成が高く，分子間および 分子内の組成がともに均一であると推定される。

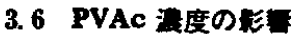

試料のケン化条件を第 4 表に， NaCl-渴度測定結果を 第 7 図に示す。
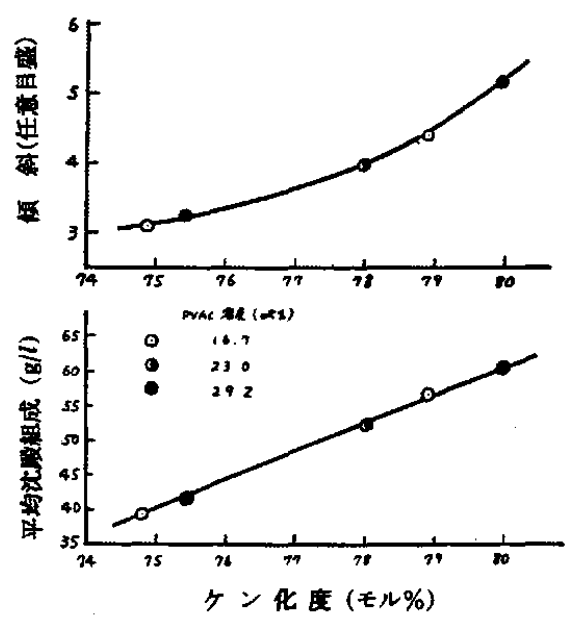

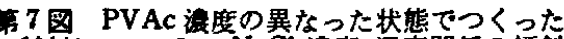
試科につ、ての $\mathrm{NaCl}$ 湌度一㵋度関系の傾斜 および平均沈殿組成

図に示すよらにすべての試料は1本の線の上にのり， 特に PVAc 涱度の差によって曲線の傾斜および平均沈 殿組成が変化するとは考えられないししたがって醀酸基

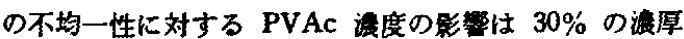
な溶腹でも無視できることがわかる。

以上ケン化条件と，部分ケン化物の分子間および分子
内の酢酸基組成との関係を検郡したが，ケン化温度が低 いほど，またケン化系の含水率が高いほど生成した部分 クン化物は，分子間組成および分子内配列状態ともに均 一であり、したがって水管液の透明度に扔いてすぐれて いることが明らかとなった。またPVAc 溶液の渡度は, 実塗籍团で恃大きい影䇾がないものと考えられる。

さて緒曾に扔いても述へたように，このよらな䣫酸基 の不均一性がケン化反応の際の加速現象によって生ずる ものとすれば，上の結果からケン化温度が滈いほど，ヶ ン化系の含水率が低いほと，加速現象が旺盛であること が結論される。従来加速現象は，温度には無関保とされ てきたしままた含水メタノール系にお汀る水の影響につ いても，あまりはっきりした結論は得られていない。加 速現象に及ぼすこれらの影繁恃，さらに詳しく梌討され なければならないが,一応次のような考察が可能である。

桜田，大杉氏33 恃水酸基の双極子と触媒イオン間の相 互作用を理論的に取り扱い，触媒の平均搌度 $C_{0}$ と双極 子の中心からてなる距離に扔ける触媒漫度Cについて次 の関係式を得た。

$$
C=C_{0} \exp \frac{\varepsilon \cdot \mu_{A} \cdot \cos \theta \cdot N}{D r^{2} R T}
$$

ここに€は静電単位, $\mu_{A}$ は双極子能率, $\theta$ は双極子の方 向と，双梗子の中心とその点を結心楾とのなす角， $D$ は溶剤の透電定数， $N$ および $R$ はつボガド口数および 気体定数である。ClC $=1$ の場合は加速現象がなく，Cl $C_{0}$ が 1 より大きいほど加速現象が旺盛となる。今の場 合，ケン化温度枋よび含水率と関保があるのは $D$ および $T$ であり，上式は $C / C_{0}=K \cdot \exp (1 / D T)$ と書きうる。 含水メタノール系について $D$ の值を求め $D T$ を計算す れば第 5 表に示すようになる。

第 5 表 ケン化条件と DT

\begin{tabular}{|c|c|c|c|c|c|c|}
\hline \multicolumn{3}{|c|}{ ケン化沮度 $30^{\circ} \mathrm{C}(T=303)$ の場合 } & \multicolumn{4}{|c|}{ 含水率 $6.0 \%$ の場合 } \\
\hline 含水率 (\%) & $D$ & $D T \times 10^{-4}$ & $\begin{array}{c}\text { ケン化温度 } \\
\left({ }^{\circ} \mathrm{c}\right)\end{array}$ & $T$ & $D$ & $D T \times 10^{-4}$ \\
\hline $\begin{array}{r}1.5 \\
6.0 \\
10.5\end{array}$ & $\begin{array}{l}32.40 \\
34.55 \\
36.65\end{array}$ & $\begin{array}{l}0.982 \\
1.047 \\
1.111\end{array}$ & $\begin{array}{r}0 \\
15 \\
30 \\
45 \\
60\end{array}$ & $\begin{array}{l}273 \\
288 \\
303 \\
318 \\
333\end{array}$ & $\begin{array}{l}41.65 \\
37.90 \\
34.55 \\
31.50 \\
28.85\end{array}$ & $\begin{array}{l}1.137 \\
1.092 \\
1.047 \\
1.002 \\
0.961\end{array}$ \\
\hline
\end{tabular}


表より明らかなように含水率が小さいほど，またケン 化温度が高いほど $D T$ は小さく，したがって $C / C_{0}$ は大 きくなり, 加速現象が旺盛になるという結果となり, 実験 事実よりの推定と一致する。このように生成部分ケン化 物の沈殿性を測定することにより, 従来ヶン化速度や加 速定数の測定からは見出しえなかったケン化温度の影響 などを検討することが可能となった。また従来のケン化 反応の研究は主として希薄溶液について行なわれてお り, 濃厚溶液の場合は系中の分子の存在確率が大きいこ と，および系の粘度上昇による拡散速度の低下などの影 響に基く加速現象の差異が本実験方法により見出される ことが期待れれたが, 従来の実験結果と同様濃度の影響
は全くみられなかった。

付 記：本報告の発表を許可された会社当局に感䝰す る。なお本報告は学協会連合秋季研究発表大会 (1959年 10 月, 於東大)において発表たし。

\section{文献}

1）桜田一郎, 坂口康義, 伊藤順夫：高化, 14, 41 (1957)

2) 高山㓮三, 私信

3) 桜田一郎, 坂口康義, 島正一郎: 高化, 13, 348(1956)

4）たとえば桜田一郎, 坂口康義, 錫木紀夫：高化，12, 27 (1955)

5）桜田一郎, 大杉鉄郎：末発表; 桜田一郎篇「ポリビ ニルアルコール」48

\title{
Effect of the Saponified Conditions on the Turbidities of the Aqueous Solution of Partially Saponified PVAc
}

\author{
By Ryunosuke Naito*
}

\begin{abstract}
The composition distribution, both intermolecularly and intramolecularly, of partially saponified polyvinyl acetate (acetyl content $20 \sim 30 \mathrm{~mol} \%$ ), which had been prepared under various conditions with sodium hydroxide in the system of methanol and water mixture, was investigated by the temperature-turbidity relations or sodium chloride concentration-turbidity relations for the aqueous solutions. (1) If the mixing of the polyvinyl acetate solution and the sodium hydroxide solution is uncomplete, the prepared samples are heterogeneous in relation to the intermolecular composition. (2) The concentration of the polyvinyl acetate solution has no effect, up to $30 \%$, on the composition distribution of partially saponified polyvinyl acetate. (3) With increase of the saponification temperature and decrease of the water content in methanol in the system of the saponification, the heterogeneity of the composition of the prepared samples increases both intermolecularly and intramolecularly. (4) The facts mentioned above, suggest that the acceleration to the rate of the saponification is more violent in the conditions of the higher saponification temperature and the lower water content.
\end{abstract}

* Toyama Factory, Kurashiki Rayon Co.Ltd. (Hasumachi, Toyama)

\section{昭和 35 年 4 月 20 日 印刷 昭和 35 年 4 月 25 日 発行 第 17 巻 第 180 号}

\section{高分子化学会員外頒価 250 円}

編集兼発行人荒井溪吉 印刷所研究社印刷株式会社

発行所社団法人高分子学会 東京都中央区日本楯本町 3 の 9 㵶維会館内 西話日本標(241) 2793 振替東京 111688 